\title{
Forsteninger fra Danmark - en ny fossilbog fra Geografforlaget
}

Anmeldt af Søren Bo Andersen, Geologisk Institut Aarhus Universitet.

I slutningen af 2005 dukkede en ny fossilbog op - den er udgivet af Geografforlaget og med dette forlags ry for smukke og gode bøger, ser man naturligvis med spænding frem til indholdet af dette seneste skud på stammen. Og jeg kan på forhånd sige, at man æstetisk får sig nogle meget gode oplevelser med bogen - der er smukke billeder og illustrationer hele vejen igennem (i øvrigt fotograferet af forfatteren, der af fag er fotograf).

Fossilbogen er en god begynderbog, som via mange kapitler fordelt på 59 sider giver en god fornemmelse for forsteninger og for nogle af de grundbegreber i geologien, der er nødvendige for den bredere forståelse.

\section{Hvad, hvordan hvor}

Bogens mål er at give $\mathrm{fx}$ den almindelige strandvandrer en fornemmelse af, hvad det er for en slags dyr eller spor, der er fundet blandt strandens sten.

Bogen har kapitler om: hvad forsteninger er, hvordan man samler og hvor man samler, lidt om geologisk tidsopdeling og Jordens historie og ikke mindst nogle-og-tyve afsnit om hver sin gruppe forsteninger - svampe, vættelys, ammonitter, snegle, muslinger,

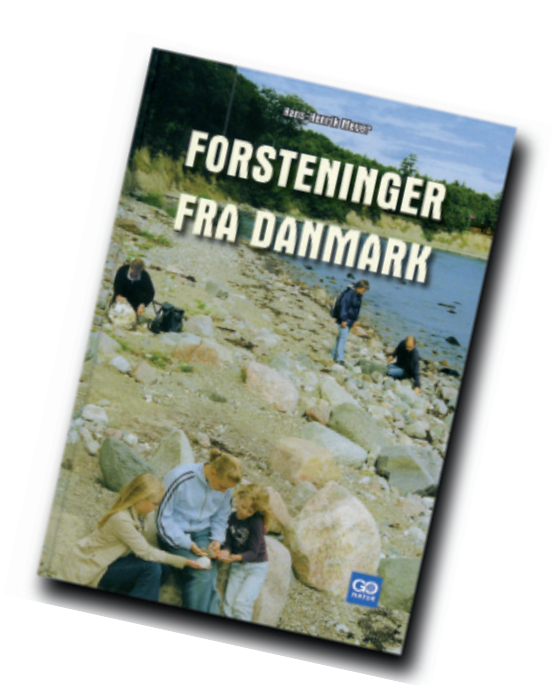

i andre bøger eller på internettet. Jeg er dog bekendt med, at der senere vil blive udarbejdet en liste over disse fossilers navne, og at denne vil kunne læses på eller hentes fra Sydsjællands Amatørgeologiske Forenings hjemmeside:

http://forening.bynet.dk/naestved/saf/index. htm

Et par suk...

Et lille suk skal lyde over forfatterens manglende stringens ved anvendelse af ordene: art, slægt og familie. Disse tre ord har i navngivningen af fossiler (og nulevende organismer) meget nøjagtige betydninger. Adskillige steder er ordet "art" brugt, hvor der formodentlig snarere kunne være brugt det mere ubestemte og ubelastede ord "gruppe" eller "slags".

Et andet suk går lidt på manglende konsekvens i stavningen af for eksempel ortoceratitter/orthoceratitter og amonitter/ammonitter - ikke at det er meningsforstyrrende, men det springer bare i øjnene. En enkelt musling har sneget sig ind på brachiopodtavlen, og en trilobit "af arten Nileus" er i virkeligheden en trilobit af slægten Illaenus.

Lad nu ikke disse suk og forbeholdende bemærkninger afholde nogen fra at investere de ca. 150 kr., som bogen koster - den er grundlæggende meget flot.

Titel: Forsteninger fra Danmark. Forfatter: Hans-Henrik Meyer. ISBN 87-7702-416-8. Udgivet af Geografforlaget 2005. Pris ca. $150 \mathrm{kr}$. 